\title{
Customers Buying Behaviour towards Organised Retail Stores in Thoothukudi City
}

\author{
Dr. A. Arunachala rajan a ${ }^{\text {, Mrs. G. Mabel granapu }}{ }^{\text {b }}$ \\ ${ }^{a}$ Assistant Professor and Head of Commerce with CS, PG and Research Centre in Commerce, Kamaraj College, Thoothukudi \\ $-628003$. \\ (Affiliated to Manonmaniam Sundaranar University, Tirunelveli \\ ${ }^{b}$ Ph.D. Research Scholar, Register No: 18122231012013PG and Research Centre in Commerce, V.O. Chidambaram College, \\ Thoothukudi
}

Article History: Received: 10 November 2020; Revised 12 January 2021 Accepted: 27 January 2021; Published online: 5 April 2021

\begin{abstract}
Retailing is a development of communicating the end customers complete the average of goods and facilities taking aids of the several channel of supply for the generation of revenue and consequently occupies a main place in the field of business. The nations that consume liked the extreme financial and common development consume remained persons with a secure retail sector. Sellers achieve detailed events, such as anticipating buyers' requirements, emerging collections of goods, obtaining marketplace material, and financing. Organized sellers are individuals who are approved for exchange actions and listed to pay duties to the administration. The present study is to identify Customer's Buying Behaviour Towards Organised Retail Stores in Thoothukudi City.
\end{abstract}

Keywords: Retailing, Organised Retail Stores, Customer, Buying Behaviou

\section{Introduction}

The world over retail business is dominated by slight domestic-track chains and locally targeted supplies. The comfort of access into marketing business outcomes in severe opposition and well price for clients. A main growth in the current periods has remained the development of wide-ranging selling setups that take ongoing working in greatest creation groups. Aimed at occurrence, there are huge branch supplies that proposal a enormous collection of goods and services. In today's modest situation, stores have redefined their part in overall, and in the cost chain in specific. The part of sellers in the current modest situation has increased the consideration of producers as outside parties, such as marketplace mediators and provision associates are attractive increasingly powerful.

Consumer behaviour also called Buyer Behaviour is the process and act of decision-making of people involved in buying and use products. Each day of our lifetime we stay purchasing and consuming a changed difference of goods and services. Though, we all consume dissimilar tastes, enjoys and hates and accept diverse behaviour designs while manufacture buying choices. Indian stores essential to recognize the price of trade as a product moderately enduring as shops marketing products. organised retailing has developed an involvement characterised by relief, elegance and speediness. It is something that suggestions a buyer extra controller, accessibility and special along with an involvement.

\section{Review Of Literature}

Aaker, D. J. \& Joachimsthaler, E ,2000) Consumers can either be subjective or objective, testing the persuasiveness of brand names. Retail stores selling the products also play an important role in swaying the decisions of consumers. The whole package or visual appeal of the retail outlet can determine sales, or the service of the sales ladies or the clerks. Furthermore, consumers may choose particular products/brands not only because these products provide the functional or performance benefits expected, but also because products can be used to express consumers' personality, social status or affiliation (symbolic purposes) or to fulfil their internal psychological needs, such as the need for change or newness.

(Bhattacharya, C.B. \& Sen, S., 2003) Consumer behaviour refers to the mental and emotional process and the observable behaviour of consumers during searching, purchasing and post consumption of a productor service. Consumer behaviour involves study of how people buy, what they buy, when they buy and why they buy. It blends the elements from Psychology, Sociology, Sociopsychology, Anthropology and Economics. It also tries to assess the influence on the consumer from groups such as family, friends, reference groups and society in general. 
Philip Kotler (2006) explained that "thus marketers must constantly improve their understanding of consumers. A consumer buying behaviour is influenced by cultural, social and personal factors. These factors are also called the determinants of consumer behaviour".

\section{Objectives Of The Study}

- To know the demographic profile of the customers.

- To know the reason for buying organised retail stores.

- To examine the customers' satisfaction towards organised retail stores.

\section{Methodology Of The Study}

Primary Data: The data were collected through questionnaire.

Secondary Data:The secondary data were collected from books, journals, websites.

Sample size: The sample size is 120 respondents in Thoothukudi city.

\section{Data Analysis And Interpretation:}

Table 1

General Profile of the respondents

\begin{tabular}{|c|c|c|c|}
\hline Particulars & Variable & $\begin{array}{l}\text { No of } \\
\text { Respondents }\end{array}$ & Percentage \\
\hline \multirow{3}{*}{ Gender } & Male & 59 & 49.17 \\
\hline & Female & 61 & 51.00 \\
\hline & Total & 120 & 100 \\
\hline \multirow{5}{*}{ Age } & Below 25year & 8 & 7.00 \\
\hline & 26 to 35 year & 24 & 20.00 \\
\hline & 36 to 45 year & 31 & 25.00 \\
\hline & Above 46 year & 57 & 48.00 \\
\hline & Total & 120 & 100.00 \\
\hline \multirow{5}{*}{ Educational Qualification } & School Level & 11 & 9.20 \\
\hline & Graduate & 16 & 13.33 \\
\hline & Post Graduate & 35 & 29.20 \\
\hline & Professional & 58 & 48.33 \\
\hline & Total & 120 & 100.00 \\
\hline \multirow{6}{*}{ Occupation } & Business & 11 & 9.17 \\
\hline & Professional & 23 & 19.17 \\
\hline & Self-Employee & 20 & 16.00 \\
\hline & House Wife & 53 & 44.17 \\
\hline & Others & 13 & 11.00 \\
\hline & Total & 120 & 100.00 \\
\hline \multirow{5}{*}{ Family Income } & Rs 10000 - Rs 20000 & 26 & 22.00 \\
\hline & Rs 20001 - Rs 30000 & 35 & 29.17 \\
\hline & Rs 30001 -Rs 40000 & 43 & 36.00 \\
\hline & Above Rs 40000 & 16 & 13.00 \\
\hline & Total & 120 & 100.00 \\
\hline
\end{tabular}

\section{Source: Primary data}


Table 1 portraits that out of 120 respondents, 51.00 percent of the respondent are female, 48.00 percent of the respondent age group of above 46 years, 48.33 percent of the respondent are professionals, 44.17 percent of the respondent are housewife and 36.00 percent of the respondent are family monthly income in Rs.30,001- Rs. 40,000 .

Table 2

Reason for buying from Organised Retail Store

\begin{tabular}{|l|c|c|}
\hline Particulars & No of respondent & Percentage \\
\hline Availability of Product & 47 & 39.16 \\
\hline Company Image & 19 & 15.83 \\
\hline Different Brands & 13 & 10.83 \\
\hline Neat arrangement (display of product) & 26 & 21.67 \\
\hline Comfortableness & 15 & 12.50 \\
\hline Total & 120 & 100.00 \\
\hline
\end{tabular}

Table 2 portrait that out of 120 respondents, 39.16 percent of respondent to buy availability of product, 21.67 percent of respondent to buy neat arrangement (display of product), 15.83 percent of respondent to buy company image, 12.50 percent of respondent to buy comfortableness and 10.83 of the respondents to buy different brands.

Table 3

Customer Satisfaction towards Organised Retail Stores

\begin{tabular}{|l|l|l|l|l|l|l|l|l|l|}
\hline S. No & Parameter & SA & A & N & DA & SDA & Total & Mean & Rank \\
\hline 1 & Quality Service & 110 & 56 & 36 & 16 & 2 & 220 & 1.83 & II \\
\hline 2 & Time Saving & 45 & 20 & 9 & 2 & 2 & 78 & 0.65 & V \\
\hline 3 & Affordable Price & 55 & 28 & 9 & 2 & 1 & 95 & 0.79 & III \\
\hline 4 & Quality of Product & 60 & 36 & 15 & 4 & 1 & 116 & 0.96 & I \\
\hline 5 & Promotion and offers & 90 & 52 & 33 & 2 & 1 & 178 & 1.48 & VII \\
\hline 6 & Good Packaging of product & 50 & 16 & 3 & 2 & 1 & 92 & 0.76 & IV \\
\hline 7 & Safety Shopping & 35 & 12 & 3 & 4 & 1 & 55 & 0.46 & VIII \\
\hline 8 & Billing Facility & 40 & 24 & 3 & 2 & 1 & 70 & 0.58 & VI \\
\hline
\end{tabular}

Table 3 reveals that the mean score of respondents in satisfaction level of organised retail stores. customers are given first rank in quality of product, second rank are given quality of service, third rank given affordable price, fourth place given good packaging of product and offers, fifth place given time saving, sixth place given billing facilities, seventh place given promotion and offers and eight place given safety shopping.

\section{Findings From The Study}

- $\quad$ Out of 120 respondents, Majority (51.00 per cent) of the respondent are female.

- Majority (48.00 per cent) of the respondent are above 46 years.

- Majority (48.33 per cent) of the respondent are professional.

- Majority (44.17 per cent) of the respondent are housewife.

- Majority (36.00 per cent) of the respondent are Rs 30, 001 - Rs. 40, 000.

- Majority (39.16 per cent) of the respondents are buying products from organised retail stores for its availability.

\section{Conclusion}

Organized retailing in India is at current in its preliminary steps and facing high development. Organized selling segment is rising quickly and customers are fluctuating to shop in organized selling stores. Customers 
always aspect for the aids of shop in an organized selling store in the terms of identity, collection, etc. The achievement of any plan of marketing business exclusively depends on how it makes in the shop place at a specified fact of period. So, kind of shoppers behaviour is the main to achievement for the stores. The organized segment in selling consumes to go an extensive method to know the buyer provisions

\section{References}

Aaker, D. J. \& Joachimsthaler, E (2000): The brand relationship spectrum: the key to the brand architecture challenge, California Management Review, USA, Vol. 42, p.42, p.8-23.

Bhattacharya, C.B. \& Sen, S. (2003): Consumer-company identification: a framework for understanding consumers' relationships with companies Journal of Marketing, American marketing Association, June, p. 67, p. 76- 88 .

Philip Kotler (2006), "Marketing Management”, Twelfth Edition, Page No. 164.

Dr.S. Sathuraman, B. Ramesh, (2016), "consumers buying behaviour towards organised retail stores in India literature review", IRJMST Vol 7 Issue 11, ISSN 2250 - 1959 (0nline) 2348 - 9367.

P Daniel, Dr. MS Narayana, P Vijay Kumar, "A study on analysing customer preferences and buying patterns towards organised retailing with reference to Spencer's retail outlet, Guntur district", International Journal of Academic Research and Development, ISSN: 2455-4197, Volume 2; Issue 6; November 2017; Page No. 1156-1159.

N Ramya, Dr. SA Mohamed Ali, A Bhuvaneshwari, “A study of consumer buying behaviour in departmental store (with special reference to Coimbatore city), ISSN Online: 2394-5869, IJAR 2017; 3(3): 734-737.

Dr. A. Arunachala rajan, P. Maria delcia, "Customers Awareness Towards Organised Retail Stores In Thoothukudi City," Studies in Indian Place Names, ISSN: 2394-3114

Vol-40-Issue-40-March-2020. 